\title{
Intercultural Gaps Between Indonesia and China on the Belt and Road Initiative
}

\author{
Causes and Remedies
}

Paulus

Rudolf Yuniarto

\begin{abstract}
In implementing the Belt and Road Initiative (BRI), there remains a huge perception gap between China and Indonesia. Differences in ideology, politics, race, religion, and ethnicity are hindering the great potential of the BRI from being fully realized. To bridge the gap and enhance mutual understanding, people-to-people exchange between both countries should be accorded greater significance. In addition, strengthening bilateral cooperation in education, labor, tourism, and culture can
\end{abstract}

Paulus Rudolf Yuniarto is Associate Researcher at the Research Center for Regional Resources, Indonesian Institute of Sciences (LIPI). His mailing address is: Jl. Gatot Subroto No. 10, Jakarta Selatan 12710, Indonesia. He can also be reached at rudolfyuniarto@gmail. com.

This paper was presented at the first Conference on Dialogue of Asian Civilizations held in Beijing, China on May 15-22, 2019. The author is grateful to Prof. Xu Liping (CASS), Dr. Zhang Zhexin (SIIS), and Dr. Thung Julan (LIPI) for their helpful suggestions and comments.

(c) 2019 World Century Publishing Corporation and Shanghai Institutes for International Studies China Quarterly of International Strategic Studies, Vol. 5, No. 3, 395-416

DOI: $10.1142 / S 2377740019500234$

This is an Open Access article, copyright owned by the SIIS and WCPC. The article is distributed under the terms of the Creative Commons Attribution-NonCommercial 4.0 (CC BY-NC) License which permits use, distribution and reproduction in any medium, provided that the original work is properly cited and is used for non-commercial purposes. 
bring positive spill-over effects beyond basic intercultural learning. Such non-infrastructure cooperation creates more room for people-to-people bonds to flourish, where economic interests are not blindly pursued. Deepened mutual understanding will, in turn, help achieve the major goals of the BRI and promote the building of a community of shared future along the route.

Keywords: Belt and Road Initiative (BRI); China; Indonesia; perception gap; intercultural exchange.

\section{Introduction}

The Belt and Road Initiative (BRI) links infrastructure investment with sustainable creation of jobs and services with human mobility. ${ }^{1}$ Initially, the Chinese government proposed five guiding principles to steer the BRI towards greater success: building it into a road of peace, prosperity, opening up and innovation, and a road connecting different civilizations. ${ }^{2}$ Up to the present day, the proposal has been extended to cover non-infrastructure investments as well, including cultural ties and people-to-people exchange while combining its internal and external economic, political, cultural, and security interests. ${ }^{3}$ The BRI is also designed to address the urgent need to promote trade, jobs, tourism, migration, and education across the region. ${ }^{4}$

${ }^{1}$ Raya Muttarak, "Moving along the Belt and the Road: Implications of China's 'One Belt, One Road' Strategies on Chinese Migration," Translocal Chinese: East Asian Perspectives, Vol. 11, No. 2 (2017), pp. 312-332.

${ }^{2}$ Huang Yiping, “Understanding China's Belt \& Road Initiative: Motivation, Framework and Assessment," China Economic Review, Vol. 40 (September 2016), pp. 314-321.

${ }^{3}$ Dragana Mitrovic, "China's Belt and Road Initiative: Connecting and Transforming Initiative," in Cheng Yu et al., eds., The Belt $\mathcal{E}$ Road Initiative in the Global Arena: Chinese and European Perspectives (Singapore: Palgrave Macmillan, 2018); Fu Xiumei, et al., "Construction of the Belt and Road Trade Cooperation Network from the Multi-Distances Perspective," Sustainability, No. 10 (2018), pp. 1-16; and Wang Yiwei, The Belt and Road Initiative: What Will China Offer the World in Its Rise (Beijing: New World Press, 2016).

${ }^{4}$ Don Kanak, "China's Belt and Road Initiative Vital to Asian Job Creation," Nikkei Asian Review, December 28, 2016, https://asia.nikkei.com/Viewpoints/Don-Kanak/China-sBelt-and-Road-initiative-vital-to-Asian-job-creation; and Dahlia Patricia Sterling, "A New Era in Cultural Diplomacy: Promoting the Image of China's 'Belt and Road' Initiative in Asia," Journal of Social Sciences, Vol. 6, No. 2 (2018), pp. 102-116. 
For Southeast Asia, an important partner of the BRI, the initiative would work to stimulate the circulation of capital, people, ideas, and socio-cultural exchange with China. ${ }^{5}$

Nevertheless, there remain many socio-cultural factors impeding people-to-people connectivity in implementing the BRI. For instance, in the case of Chinese investment in Indonesia, these factors stretch across such diverse fields as culture, security and finance. As Negara and Suryadinata note, there are four factors hindering the cooperation between Indonesia and China: perceptions of China's economic dominance, issues related to the rise of ethnic Chinese in Indonesia, the issue of Chinese occupation in the Natuna Islands, and the movement of Chinese labor in Indonesia. ${ }^{6}$ Far from considering the BRI as a means of promoting people-to-people connectivity, the Indonesian government perceives it largely as an opportunity for infrastructure projects financed by Chinese capital, ${ }^{7}$ while China tends to look at Indonesia as a country of islands with inadequate infrastructure and diverse cultures. As Indonesia's image has been tainted by issues like terrorism, sectarian conflicts, and May 1998 riots, ${ }^{8}$ various concerns related to cooperation under the BRI have arisen from the country's socio-political situation.

In addition to perceptions, there is also a gap in perspectives, which may result in misunderstandings and negative assessment of the BRI projects. By analyzing social and political relations between Indonesia and China, this study poses the following questions: What causes the different perceptions between Indonesia and China on the BRI, an obviously beneficial initiative for both? And how to bridge the perceptual gaps? This article aims to explain the importance of people-to-people exchange under the framework of the BRI in order to understand the ways in which

${ }^{5}$ Parag Khanna, Connectography: Mapping the Future of Global Civilization (New York: Random House, 2016).

${ }^{6}$ Siwage Darma Negara and Leo Suryadinata, Indonesia and China's Belt and Road Initiatives: Perspectives, Issues and Prospects (Singapore: ISEAS, 2016).

${ }^{7}$ Diana J. Mendoza, “China's Belt and Road Initiative: Challenges from Within and Without," Ateneo de Manila University, July 6, 2017, http://ateneo.edu/news/research/china $\%$ E2\%80\%99s-belt-and-road-initiative-challenges-within-and-without-blueboard-diana-j.

${ }^{8}$ Tonny Dian Effendi and Zhang Lidong, "The Image of Nation: Case Study on Chinese Student Perception about Indonesia," Global Journal of Arts, Humanities and Social Sciences, Vol. 3, No. 11 (November 2015), pp. 33-39. 
the socio-cultural narrative draws on the two countries' socio-cultural relations.

This article consists of three main sections. The first section discusses perceptions of the Indonesian elite and public on China and its investment under the BRI and explains how the economic imbalance between both countries has given rise to negative perceptions on the initiative. The second section examines the central issues - in particular, tourism, labor migration, student and cultural exchange - in the bilateral social-economic relations under the framework of the BRI. The third section explores the challenges and possible solutions in enhancing people-to-people connectivity within the BRI. It is concluded that intercultural communication can further bolster Indonesia-China cooperation if the BRI actors remain attentive to the dynamics of the social impact of people-to-people bonds and other cultural interrelations between the two countries.

This study was conducted in Indonesia (Jakarta) and China (Beijing and Shanghai) in 2017-2018. In general, it adopted a qualitative approach and gathered the primary data mostly through in-depth interviews concerning the role of "non-infrastructure" or people-to-people exchange in facilitating the implementation of the BRI. Informants included officials, scholars and researchers in Indonesia and China, who were concerned with these issues in one way or another. The modus operandi was to conduct focus group discussions with members from the National Institute of International Strategy (NIIS), the Chinese Academy of Social Sciences (CASS); China Institute of International Studies (CIIS); Ministry of Foreign Affairs, Indonesia; Shanghai Institutes for International Studies (SIIS), and Beijing Foreign Studies University (BFSU). The data for this study were also gathered from a focus group discussion on "the Impact of the Belt and Road Initiative on Society and Culture 2018," a seminar hosted by the Academy of Chinese Culture and Indonesian Institute of Sciences in Beijing. In order to employ findings from previous studies, the data gathered from focus group discussions is combined here with literature survey.

\section{Indonesian Perceptions on Chinese BRI Investment}

As one of the most valued members of the China-initiated BRI, Indonesia was invited to join in the initiative at the very beginning. Indonesia ranks as the 4th most populous country in the world and is home to more than 200 
ethnic groups that have been living in relative peace. In addition, Indonesia has the largest Muslim population in the world, while the pluralistic society promotes moderate Islam and advocates democracy. In this way, Indonesia has emerged as one of the largest democracies in the world. Furthermore, political and economic stability over the past decade has enabled current Indonesian leaders to resume an active role in international relations and global politics. Thus, China's decision to invite Indonesia into the BRI is quite understandable. ${ }^{9}$

In turn, China can offer much of what Indonesia needs through

Indonesia and China have been working on the BRI since its launch. the BRI, especially in technology transfer and infrastructure investment. For Indonesia, investment in infrastructure sectors is generally appreciated, as infrastructure development is crucial for the Indonesian economy and infrastructure problems in many sectors are hindering foreign direct investment (FDI) attraction and industrial growth. ${ }^{10}$ Development in transportation and logistics, energy, water management (for irrigation and public consumption), as well as information and communications technology (ICT) infrastructure will not only contribute to Indonesia's competitiveness, but it is also needed to address the current supply crisis in the country. Through joint infrastructure development, Indonesia can capitalize on its demographic advantages (such as labor force and tourism) to ensure economic growth. The Maritime Silk Road, for instance, accords well with Indonesian President Joko Widodo (Jokowi)'s domestic vision of the "Sea Toll" based on Indonesia's strong maritime heritage. ${ }^{11}$

China has become Indonesia's key economic partner in recent years. In 2017, China was the second largest investor with infrastructure drive in the

${ }^{9}$ Evi Fitriani, “Indonesian Perceptions of the Rise of China: Dare You, Dare You Not," The Pacific Review, Vol. 31, No. 3 (2018), pp. 391-405.

${ }^{10}$ Samti Wira Wibawati et al., "The Potential and Challenges of One Belt One Road (OBOR) for Indonesia's National Maritime Interests," Jurnal Kajian Wilayah, Vol. 9, No. 2 (2018), pp. 109-123.

${ }^{11}$ Nanto Sriyanto, "Global Maritime Fulcrum, Indonesia-China Growing Relations, and Indonesia's Middlepowermanship in the East Asia Region," Jurnal Kajian Wilayah, Vol. 9, No. 1 (2018), pp. 1-19. 
Indonesian economy. ${ }^{12}$ In 2018, China was the third largest investor in the country, with investment worth $\$ 2.3$ billion covering 1,562 projects. ${ }^{13}$ The governments of both China and Indonesia have agreed to jointly develop infrastructure projects in four Indonesian provinces specifically marked out for BRI investment, namely, Bali, North Kalimantan, North Sumatra, and North Sulawesi. ${ }^{14}$ The funding in infrastructure under the BRI covers three sectors - transport, industry and tourism - and includes the construction of ports, airports, railways and a cruise terminal. ${ }^{15}$ Chinese investors also invest in the smelter and power plant sectors. While Chinese exports to Indonesia are mainly high value-added goods and high-tech items such as electronics and machinery, Indonesia's exports to China remain mostly

${ }^{12}$ According to the data released by Indonesia's Investment Coordinating Board (BKPM), China overtook Japan on the Southeast Asian countries' investors' list and now trails only behind Singapore. Investment from Japan, the runner-up in 2016, dropped to 7 percent ( $\$ 5$ billion) in 2017. South Korea won the 4th place, followed by the United States; the Netherlands lost its place in the top-five placement, which it held from 2014 to 2016. See Erwida Maulia, “China Becomes Indonesia's No. 2 Investor with Infrastructure Drive," Asian Review, February 1, 2018, https://asia.nikkei.com/Politics-Economy/International-Relations/ China-becomes-Indonesia-s-No.-2-investor-with-infrastructure-drive.

${ }^{13}$ Such increasing figures are accompanied by around 1,000 Chinese companies and 25,000 Chinese workers present in Indonesia. While top-ranking Singapore poured in $\$ 8.4$ billion, combined investment from Chinese mainland and Hong Kong surged to $\$ 5.5$ billion, or 12 percent of the total foreign investment in Indonesia. See Muhammad Zulfikar Rakhmat and Andry Satrio Nugroho, "How Can Indonesia Take Advantage of the Belt and Road's Opportunities?," The Diplomat, March 20, 2019, https://thediplomat.com/2019/03/how-canindonesia-take-advantage-of-the-belt-and-roads-opportunities/.

${ }^{14}$ It was reported in 2018 that China's trade with Indonesia reached $\$ 72.6$ billion, a 23.5 percent rise from the previous year. This growth rate is slightly less than the one from 2017 when it witnessed a growth of 23.7 percent. See Jumat, "Indonesia-China teken kerja sama Jalur Sutera 23.3 miliar dollar," Antara News, April 13, 2018, https://kepri.antaranews.com/ nasional/berita/701368/indonesia-china-teken-kerja-sama-jalur-sutera-233-miliar-dolar? utm_source=antaranews\&utm_medium= nasional\&utm_campaign= antaranews.

${ }^{15}$ At the Belt and Road Forum held on May 14 and 15, 2017 in Beijing, China, Indonesian President Joko Widodo and Chinese President Xi Jinping had a bilateral meeting and signed three documents. The first was related to an action plan for the implementation of a comprehensive strategic partnership from 2017 to 2022 . The second was related to a 150 billion Indonesian Rupiah (\$11.25 million) grant for financing a site study on infrastructure development. The third was related to the financing agreement of the Jakarta-Bandung high-speed railway project. 
resource-based commodities such as coal and crude palm oil. ${ }^{16}$ Besides trade advantages based on the infrastructure investment, the massive flow of Chinese workers into Indonesia has also opened up many new opportunities for Chinese firms.

However, the BRI projects in Indonesia often highlight the weakness of Chinese firms in understanding the local cultures. Business is personal in Indonesia. In doing business, people spend time on daily communication to build and maintain strong relationships. For Indonesians, time does not bring money, but good relations and harmony do. ${ }^{17}$ Yet, a survey by Gong Xue shows that Chinese investors seem to have difficulties in understanding and adapting to local employees' work ethics. ${ }^{18}$ Another survey conducted by Zhai Kun on relations between China and ASEAN (Association of Southeast Asian Nations) countries shows that the relations of cooperation for Singapore, Thailand, Malaysia and Indonesia have a standard score of at least 8 points out of 10 (which means that the relative degrees of mutual understanding for these countries are excellent), while those for Cambodia and Laos have a score of 6.95 and 6.53 respectively (good); even the scores for Vietnam, Myanmar, the Philippines and Brunei are little less

${ }^{16}$ Inclusive Development International, Making Inroads: Chinese Infrastructure Investment in ASEAN and Beyond, https://www.inclusivedevelopment.net/wp-content/uploads/2016/08/ Making-Inroads-China-Infrastructure-Finance.pdf.

${ }^{17}$ Cristiana Victoria Marta Davidescu, "Culture and Ethics in Indonesian Business," Proceedings of the International Conference on Business, Entrepreneurship and Management, College of Arts and Sciences, San Beda College, Manila, Philippine (2012).

${ }^{18}$ For example, Chinese managers value efficiency and thus can be quick in dismissing local workers as inefficient and falling short of their expectations. Chinese investors feel frustrated when they realize that local employees are not even motivated by financial incentives to increase productivity. Therefore, they prefer to bring in workers from China, a move often harshly criticized by the local community for depriving its people of employment opportunities. Many Chinese companies investing overseas lack knowledge of how labor unions work and often do not respond adequately to demands of employees. Some Chinese firms bypass the laws and regulations without offering contracts or insurance, since they are accustomed to the domestic approach of relying on a variety of connections and resources to settle various problems. See Gong Xue, "Why Some in South-east Asia still Have Reservations about China's Belt and Road Initiative," Today, March 20, 2018, https:// www.todayonline.com/commentary/why-some-south-east-asia-still-have-reservationsabout-chinas-belt-and-road-initiative. 
than 6 points (which means they have the potential to thrive). In contrast, the score of the partnerships with the Chinese is a meager 4 points. This is in large part due to the negative perceptions of China developed from such actions as conducting military operations in the South China Sea that may endanger its relations with certain countries; ${ }^{19}$ it may also derive from the regional fear of the so-called "Chinese hegemony." ${ }^{20}$ These two arguments are often seen in the analysis of the asymmetry between the China-led BRI and the economic realities of the Southeast Asian region.

In some countries, the BRI is perceived to have the potential to undermine their sovereignty, weaken the leadership, and impede their long-term economic progress. In Indonesia, investment under the BRI has witnessed some major obstacles, especially public opinion against (hyped) Communist aggression and religious diffusion, and the migration of Chinese labor. There are also several concerns on the Chinese side, including the history of

ASEAN nations tend to be suspicious toward the BRI largely due to their negative perceptions of China. the Indonesian Communist Party, Islamic extremism, disputes between natives and non-natives, and anti-Chinese movements. ${ }^{21}$ In fact, antiChinese sentiment still lingers in parts of Indonesian society; the attempted coup in 1965 is not likely to be forgotten any time soon. That event blamed on the Indonesian Communist Party that was allegedly backed by the Chinese Communist Party - sparked a communist witch-hunt in Indonesia, which left about 500,000 people dead between 1965 and 1966. This led to the Jokowi (the incumbent president) administration's decision to designate North Sumatra, North Kalimantan, North Sulawesi and Bali as the economic corridors for Indonesia's "Global Maritime Fulcrum," a

${ }^{19}$ Zhai Kun and Wang Lina, "A Study of the 21st Century Maritime Silk Road in the Perspective of the People-to-people Bond Index between China and ASEAN [一带一路背景下的中国-东盟民心相通现状实证研究], Journal of Yunnan Normal University (Philosophy and Social Science Edition), Vol. 48, No. 6 (2016), pp. 55-60.

${ }^{20}$ Johanes Herlijanto, "Public Perceptions of China in Indonesia: The Indonesia National Survey," ISEAS Perspective, No. 89 (2017), pp. 1-11.

${ }^{21}$ Minutes of the Meeting on Symposium of the Belt Road Initiative between P2SDRLIPI and the Academy of Chinese Culture, April 2018. 
project that overlaps with the BRI. ${ }^{22}$ To a large extent, it is a strategy both to protect Chinese investments and to make sure that these investments stay out of sensitive areas where they may trigger strong public dissent.

Indonesian senior analyst Pattiradjawane observes that up to the present day, Indonesians, even those living in big cities, have been surprisingly unaware of China's growing geo-economic and geopolitical significance. ${ }^{23}$ As he finds out, China's economic development during the past decades appears to have left no impression whatsoever among the Indonesian middle class. In an Indonesia National Survey Project (INSP) survey, to the question "What is China best known for," a majority of the respondents came out with "traditional medicine" as their answer; the second top answer was that China is known for its "strong culture"; and the country's "communist ideology" came as the third. ${ }^{24}$ Such an understanding of China does not help Chinese projects sell well among the Indonesian public.

The negative perceptions of China are also characterized by the sentiment against the ethnic Chinese diaspora, ${ }^{25}$ a remnant from Suharto's "New Regime" era. The role of a small group of rich, ethnic Chinese Indonesian population associated with Suharto can hardly be ignored when considering Indonesia-China relations. President Suharto had close relations with privileged Chinese Indonesians whose business networks reached South China where the great grandparents of the Chinese diaspora came from. ${ }^{26}$

Increasing Chinese labor is a major concern of Indonesian society as well. According to the above-mentioned INSP survey, 26.6 percent of the

${ }^{22}$ Hui Yew-Foong, "As Belt and Road Investments Flow into Indonesia, Chinese Firms must Learn to Navigate Culture Shock," May 3, 2019, https://www.scmp.com/week-asia/ society/article/3008679/belt-and-road-investments-flow-indonesia-chinese-firms-must-learn.

${ }^{23}$ Rene L. Pattiradjawane, "The Indonesian Perspective Toward Rising China," Asian Journal of Comparative Politics, Vol. 1, No. 3 (2016), pp. 260-282.

${ }^{24}$ Diego Fossati et al., The Indonesian National Survey Project: Economy, Society, and Politics (Singapore: ISEAS, 2017).

${ }^{25}$ Evan A. Laksmana, "Variations on a Theme: Dimensions of Ambivalence in Indonesia-China Relations," Harvard Asia Quarterly, Vol. 12, No. 1 (2011), pp. 24-31.

${ }^{26}$ Christine Susana Tjhin, "Indonesia's Relations with China: Productive and Pragmatic, But Not Yet a Strategic Partner," China Report, Vol. 48, No. 3 (2012), pp. 303-315. 
respondents think that Chinese migrants should never be allowed to work in Indonesia. The majority (50.2 percent) think that they should be allowed to work but the government should limit the number, whereas 19.9 percent of the respondents think that they should be allowed to work in Indonesia only if they have high qualifications. ${ }^{27}$ This finding demonstrates that the Indonesian public have quite little tolerance towards Chinese migrant workers: although highly-skilled Chinese workers, such as technicians and managers, are welcomed, most people oppose the coming of workers with low skills, for they are considered to threaten the local job markets.

Chinese business models are unfamiliar to people in Indonesia, and this creates mistrust. ${ }^{28}$ In general, the Indonesian government regards China as a potential strategic partner, especially in terms of investment, yet the same cannot be said for the Indonesian private sector, in particular for small- and medium-scale Indonesian businesses, many of which have been shut down as they could not compete with cheap products flooding from China over the past decade. The competition prevails despite the fact that many Chinese products have gained much notoriety for poor quality. According to a study by the Research Center for Regional Resources, Indonesian Institute of Sciences (P2SDR-LIPI), if this condition continues, stronger resistance may arise from Indonesian small-scale enterprises against Chinese products. ${ }^{29}$ There is also the concern that China's economic predominance brought "more (Indonesian) dependence on China," and in

${ }^{27}$ Ibid.

${ }^{28}$ In one case in 2017, Chinese managers of one company threatened to dismiss the local workers and even intimidated the leaders of the union that demanded for better working conditions. This led to massive demonstrations in front of the Chinese embassy by unions such as the SEBUMI-NANBU (Serikat Buruh Bumi Manusia-Nanbu) and the KASBI (Kongres Aliansi Serikat Buruh Indonesia, one of the largest unions in Indonesia). The issue dominated headlines in the Bahasa-language media in Indonesia, leading to an outcry against the company in question. Realizing the power of Indonesian unions, the Chinese company eventually softened its stance and agreed to meet all the demands made by employees, including offering permanent positions, medical welfare, staff training and improving safety. See Gong, "Why Some in South-east Asia still Have Reservations about China's Belt and Road Initiative."

${ }^{29}$ Paulus Rudolf Yuniarto et al., Laporan Penelitian Praktik China Belt Road Initiative Bidang Sosial-Politik, Ekonomi, dan Budaya (Jakarta: P2SDR-LIPI, 2018). Unpublished. 
the cooperation China will benefit the most, while other participating countries will reap only marginal benefits. ${ }^{30}$

Disregarding local conditions may render a state-to-state cooperation agreement hard to implement.

Perceptions related to other domestic problems in both countries will influence people's views on the BRI, too. Those problems include corruption, goods of poor quality, social injustice, energy dependence, terrorism and drug trafficking, and religious conflicts, among other things. Such internal conditions and factors have thwarted the success of the BRI to a certain degree. In this way, a cooperation agreement made at the elite level cannot be fully executed by the local government; and the local security situation sometimes creates major disruptions for the progress of the BRI. ${ }^{31}$

In sum, Indonesian perceptions of the BRI vary according to specific stakeholders, dimensions of China's rise, and time. There are also changes in perceptions as people are influenced by domestic political changes, the course of events in Indonesia-China relations, and Indonesia's relations with Western powers. All these pose major obstacles to the success of the BRI in Indonesia.

\section{Bilateral Non-Infrastructure Cooperation}

Understanding each other's economic culture is crucial to further promoting Indonesia-China economic cooperation. China should not only export goods and make business investments, but it should also work with the Indonesian government to enhance exchange and cooperation between both peoples and societies.

\section{Tourism Development}

The BRI has introduced new ideas on tourism development, which will drive China's cruise tourist economy toward a brand new era. In fact, the

${ }^{30}$ Cheng Yu et al., eds., The Belt and Road Initiative in the Global Arena: Chinese and European Perspectives (Singapore: Palgrave MacMillan, 2018).

${ }^{31}$ Interview with researchers at NIIS-CASS, Beijing, April 2018. 
focus of China's cruise economy is shifting from speed and quantity to quality and upgrading. According to the China Cruise Shipping Agency, the BRI boasts the most elite collection of tourist resources, bringing together 80 percent of the world's cultural heritage elements covering more than 60 countries and 4.4 billion people. As the China National Tourism Administration predicts, China is expected to transport 150 million Chinese tourists, who will spend $\$ 200$ billion in the BRI countries, during the 13th Five-Year Plan period (2016-2020). In return, China will attract 85 million tourists from the BRI countries, bringing in about $\$ 110$ billion as tourist revenues. ${ }^{32}$

With regard to tourism from China to Indonesia, President Jokowi noted at the First Belt and Road Forum that he had signed a memorandum of understanding (MoU) with Beijing, pursuant to which Indonesia would like to have 10 million tourists from China by $2019 .{ }^{33}$ Indonesia aimed to attract 20 million foreign tourists in 2018-2019, and expected that China would account for half of them. In fact, China has become the second largest source of foreign visitors for Indonesia, second only to Singapore, thanks in part to Jakarta's visa exemption policy for Chinese tourists. There has been a significant increase in the number of Chinese visitors to Indonesia since 2005. In 2016, the number of visitors from China reached 1.6 million. ${ }^{34}$

Meanwhile, Indonesia faces many challenges in tourism development, including poor infrastructure and services, shortage of skilled tourism workers, a weak environment to nurture private investment, and inadequate inter-agency coordination, especially in monitoring and preserving

${ }^{32}$ The number of Chinese tourists departing from domestic ports jumped from less than 20,000 in 2006 to 2.14 million in 2016, making up more than 40 percent of the Asian cruise market. Eight international cruise liner ports have been built in Chinese cities such as Shanghai, Tianjin, and Sanya in order to serve the growing demand for cruise travel. See Ma Zhiping, "Belt and Road Initiative Drives Cruise Tourism," China Daily, November 8, 2017, http://www.chinadaily.com.cn/business/2017-11/08/content_34282543.htm.

${ }^{33}$ Estu Suryowati, "Banyak Penerbangan Langsung, Indonesia Diserbu Turis China," Kompas, October 3, 2016, http://ekonomi.kompas.com/read/2016/10/03/145126826/banyak. penerbangan.langsung.indonesia.diserbu.turis.china.

${ }^{34}$ Ibid. 
natural and cultural assets. ${ }^{35}$ Indonesia needs $\$ 20$ billion to develop tourist destinations, including 10 places dubbed as "the new Bali"; and it expects foreign investors to pay half of the bill. China is projected to be one of its biggest backers, thanks to Indonesia's participation in the BRI. ${ }^{36}$

What should be noted is that the rapid increase in the number of Chinese visitors is a double-edged sword for the local economy. On one hand, a thriving tourism directly creates demand in the tourism sector and the benefits trickle down to other sectors,

Indonesia and China need to minimize the side effects of rapidly increasing bilateral people-to-people exchange. such as transport and communication. On the other hand, many travel agents or tour operators sell tour packages at very low prices, sometimes even "zero-dollar tours." Such cutthroat competition is unhealthy for the tourism market in the long term. Besides, the flooding of Chinese tourists may further aggravate the perceptions of Indonesian public on China due to environmental disruption, inappropriate tourist behavior, or cultural differences, which must be addressed with patience and care by both sides.

\section{Labor Migration}

The number of Chinese migrants to Indonesia has been rising steadily. A close look at the regions along the Belt and Road and Africa (where Chinese foreign direct investment is concentrated) shows that the rate of migration from China witnessed a substantial increase in these regions in 2015 compared with the early 1990s. The growth can be observed in the largest proportion in West Asia (524 percent), East Africa (297 percent) and South Africa (126 percent). The rising number of Chinese migrants in Africa has coincided with the growth of China's trade with and investment in

${ }^{35}$ Yuniarto et al., Laporan Penelitian Praktik China Belt Road Initiative Bidang Sosial-Politik, Ekonomi, dan Budaya.

${ }^{36}$ Jumat, "Indonesia-China teken kerja sama Jalur Sutera 23.3 miliar dollar." 
these countries. ${ }^{37}$ The Chinese migration to developing countries in Asia and Africa often comprises Chinese civil servants, temporary labor migrants linked to state-funded Chinese investment projects, small-time entrepreneurs, in-transit migrants and agricultural workers. ${ }^{38}$

According to Indonesia's Ministry of Manpower, corresponding to the Chinese labor migration to Indonesia, the number of Chinese work-permit holders in Indonesia jumped to 21,271 in 2016, a 30 percent increase within a two-year timeframe. In comparison, there were 12,490 work-permit holders from Japan and 2,812 from the United States in the same year. ${ }^{39}$ Several infrastructure development projects are carried out by Chinese workers at various locations in Indonesia. One of these is Celukan Bawang PLTU development in Buleleng, Bali Island, which is undertaken by four contractors: China Huadian Power Plant, China Huadian Engineering Co. Ltd, PT CR 17, and PT General Energy, Bali, the local partner. ${ }^{40}$

However, rumors were spread in the Indonesian social media that there were about 10 to 20 million Chinese migrant workers in Indonesia. It was suspected that political motivation was behind the rumors, spreading the fear that Chinese would take over local jobs. Later, the Minister of Manpower refuted that figure, explaining that the number of Chinese workers in Indonesia was only around 21,000 and they mostly worked in

${ }^{37}$ Giles Mohan et al., Chinese Migrants and Africa's Development: New Imperialists or Agents of Change? (London: Zed Books, 2014). It is worth mentioning that the increase in the number of Chinese migrants is not confined to the BRI regions, but also occurs in other parts of the world such as Southern Europe (781 percent), Australia and New Zealand (420 percent) and North America (198 percent). See Raya Muttarak, "Potential Implications of China's 'One Belt, One Road' Strategies on Chinese International Migration," Vienna Institute of Demography Working Papers, No. 05/2017, Austrian Academy of Sciences, Vienna Institute of Demography (VID), Vienna. Change?

${ }^{38}$ Mohan et al., Chinese Migrants and Africa's Development: New Imperialists or Agents of

${ }^{39}$ Eveline Danubrata and Gayatri Suroyo, "In Indonesia, Labour Friction and Politics Fan Anti-Chinese Sentiment," Reuters, April 18, 2017, https://www.reuters.com/article/usindonesia-election-china/in-indonesia-labor-friction-and-politics-fan-anti-chinese-sentimentidUSKBN17K0YG.

40 “Thousands of Chinese Workers Enter Indonesia," Tempo.co, August 31, 2015, https://en.tempo.co/read/news/2015/08/31/055696470/Thousands-of-Chinese-WorkersEnter-Indonesia. 
Chinese construction projects; Chinese workers may live and even settle in Indonesia, but the impact of the Chinese labor force upon Indonesia's labor market is minimal. Notwithstanding, since then, it has become more difficult for Chinese-Indonesian joint venture companies to employ Chinese mainland workers, which may slow down the implementation of some Chinese investment projects. ${ }^{41}$

\section{Educational Exchange}

The relations between Indonesia and China under the BRI have witnessed a smooth development in the sphere of educational exchange. The Chinese government announced that 30,000 government scholarships would be awarded to students from the member states of the Shanghai Cooperation Organization (SCO). President $\mathrm{Xi}_{\mathrm{i}}$ also mentioned plans to invite another 10,000 teachers and students from Confucius Institutes in these countries to visit China for study tours. In addition, there are Chinese Government Scholarships, the Chinese Government Special Scholarship Program, the Distinguished International Students Scholarship Program, the Chinese Culture Research Fellowship Program, and short-term scholarships for Chinese language studies. ${ }^{42}$

China is becoming one of the top destinations for young Indonesians for furthering their education. Since 2010, the number of Indonesian students in Chinese universities has reached 13,700, the majority of whom are enrolled in the department of Chinese languages. According to the Chinese Service Centre Exchange (CSCSE), the number of Indonesian students in China has increased 10 percent annually over the past several years. While the majority of them have studied Chinese language and literature, the number of those entering other fields of studies - science, technology, and medicine, for example - is also on the rise. It is expected that many more young Indonesians will go to China to study technology, agriculture, healthcare and other disciplines. Studying in China provides a great

${ }^{41}$ Siwage Darma Negara, “Opinion: The Importance of One Belt One Road for Indonesia," The Jakarta Post, May 29, 2017, http://annx.asianews.network/content/opinion-importance-one-belt-one-road-indonesia-47002.

${ }^{42}$ Marlene Laruelle, China's Belt and Road Initiative and Its Impact in Central Asia (Washington. D.C.: The George Washington University, 2018). 
opportunity to learn the world's most-spoken language Mandarin, hence provides an added advantage in career advancement. ${ }^{43}$

Moreover, Indonesia and China have established six pairs of university-to-university cooperation, such as that between Peking University and University of Indonesia (UI), and that between Tsinghua University and Bandung Institute of Technology (ITB). Some Chinese universities have also started cooperation with Yogyakarta State University (UNY). Traditional medicine cooperation is considered a priority scientific program for both countries. In the field of transport, Indonesia is quite interested in learning the technology of high-speed rail; and cooperation in this field is ongoing between an Indonesian research institute (BPPT) and its Chinese partners (Nanjing Institute of Railway Technology and Chinese HTGR research center in Tsinghua University). Bilateral

Indonesia-China educational and cultural exchange has expanded rapidly under the BRI. scientific cooperation is expected to be further enhanced as well. ${ }^{44}$

\section{Cultural Exchange}

Indonesia and China have maintained close cultural cooperation in the forms of professional exchange, performances, exhibitions and training in arts, museums, cultural heritage and culinary practices since the establishment of bilateral diplomatic relations in 1950. To encourage the alignment of the BRI and Indonesia's development strategies with the development of the ASEAN community, it is necessary to promote the social and cultural exchange between the two countries and to foster an open and inclusive "soft environment." To that end, the 2nd Session of the Indonesian-Chinese Deputy Prime Ministers' Inter-Cultural Exchange Mechanism was held in Guiyang, China in August 2018, on which both

43“Indonesians Studying in China Rising in Number," May 31, 2015, http://www. studyinchina.com.my/web/page/indonesians-studying-in-china-rising-in-number/.

${ }^{44}$ Achmad Syaputra, "Indonesia-PR China Agreed to Encourage the Bilateral Scientific, Technology and Higher Education," March 9, 2017, http://international.ristekdikti.go.id/ 2017/indonesia-prc-decided-to-materialize-cooperation-on-transfer-of-technology/. 
sides declared to collaborate in the fields of education, science and technology, culture, health, sports, tourism, youth welfare and media.

One example of Indonesian-Chinese cultural cooperation is digitalized film: China provides assistance for the restoration of old Indonesian films, which is carried out by the China Film Association (CFA) under the BRI. The CFA has a studio equipped with state-of-the-art devices that has been able to restore 200 titles in one year, while Indonesia represented by the Creative Economy Agency (BEKRAF) is able to restore only five films a year. In addition to the equipment, the CFA also has warehouse space for storing old films. The CFA has expressed its willingness to export the technology of restoring old films to Indonesia, wherein it will cost around IDR600 million and take approximately two weeks to restore one title. Indonesia has planned to spend IDR4 billion in five years on this account. ${ }^{45}$

\section{To Promote Intercultural Understanding Under the BRI}

Based on the above analysis, three crucial issues can be identified with regard to the future progress of the BRI in Indonesia: First, a lack of knowledge of both countries about each other is a major cause of increasing yet unfounded fear about China and the BRI in Indonesia. Second, Indonesian public opinion on the BRI is under heavy influence of national and local media's daily coverage on China and the BRI. And third, perceptions of the BRI in governments, corporations, and educational institutions of Indonesia are significantly better than public opinion, thanks in large part to the ever strengthening exchange and cooperation with China. ${ }^{46}$ Therefore, while enhancing economic cooperation, China and Indonesia need to work together to dissolve the social and political barriers to the further development of their bilateral relations, including ethnic differences, cultural friction, religious diversity and different work ethics.

As stated by President $\mathrm{Xi}$, "Friendship between nations lies in the mutual affinity of the people, which is a result of the mutual connection of

${ }^{45}$ Muhamad Irfan Ilmie, "China Tawarkan Kerjasama Restorasi Film Kuno," Antara News, September 18, 2018, https://www.antaranews.com/berita/749432/china-tawarkankerja-sama-restorasi-film-kuno.

${ }^{46}$ Fieldwork notes from focus group discussion with Deputy Asia and Africa, Indonesian Ministry of Foreign Affairs and staff, Jakarta, April 2018. 
hearts（国之交在于民相 亲，民相亲在于心相通)." ${ }^{\prime 7}$ The BRI in Indonesia has the potential to raise Indonesian-Chinese relations to new heights through enhanced mutual understanding between both peoples. Intercultural understanding considers give and take as an important strategy for handling cultural differences and formulating appropriate acculturation among different countries. It is thus imperative for the two governments to adopt an intercultural approach ${ }^{48}$ to facilitate the mutually beneficial cooperation, so that people can learn to see things through the eyes of others and add others' knowledge to their personal repertories in order to develop intercultural communication competencies. ${ }^{49}$

Theoretically and practically, the intercultural idea is useful for the BRI. As noted by Dai and Cai in their study on cross-cultural management in the BRI, the intercultural strategy consists of three ways: (1) investigating the local markets and identifying the cultural differences between the host country and the target country; (2) cultivating intercultural communication competence of the cross-cultural employees; and (3) acculturating to the local society and making innovations based on cultural fusion. ${ }^{50} \mathrm{Wu}$ and Ruan's article on cross-culture and the BRI concludes that it is necessary to build a human resource management system based on the background of cultural differences in the transnational operation of enterprises; by

${ }^{47}$ Xing Liju, “The Humanistic Exchanges Beneficial to the 'Belt and Road Initiative': Difficulties and Their Possible Solutions," International Issues Research, Vol. 6 (2016), pp. 5-17.

${ }^{48}$ Interculturalism is a view that "recognizes that cultures are more fluid than ever before and the inter-connectedness of the world demands interaction between and within cultures to build trust and understanding, and that a high level of cultural navigational skills will be necessary to enable people to accept and endorse the change process." See Ted Cantle, "Interculturalism as a New Narrative for the Era of Globalization and Super-diversity," in Martyn Barrett, ed., Interculturalism and Multiculturalism: Similarities and Differences (Strasbourg: Council of Europe, 2013), pp. 1-19.

${ }^{49}$ Thung Julan, "Intercultural Learning in Response to China's One Belt One Road Initiative," paper presented at the First International Seminar \& Roundtable Meeting on "Professional Chinese Teaching" in Southeast Asia, 2018, http://china.uai.ac.id/wp-content/ uploads/2019/02/Intercultural-Learning-in-Response-to-China\%E2\%80\%99s-One-Belt-OneRoad-Initiative.pdf.

${ }^{50}$ Dai Guiyu and Cai Yi, “The Cross-Cultural Management of Chinese Enterprises in Poland under the Belt and Road Initiative - Based on PEST Model," International Business Research, Vol. 10, No. 9 (2017), pp. 1-19. 
establishing a scientific training mechanism of corporate culture and a working system in terms of talent and incentive management, employees can better identify with the corporation and improve their working efficiency. ${ }^{51}$ Some other scholars also suggest identifying the existing cultural differences, "to have a specific culture training, field study, situational dialogue as well as role plays, etc., so as to break the cultural barriers and shake off the bondage of roles." ${ }^{52}$ In addition, since the intercultural dialogue is a matter of highest importance if mankind and society are to survive, Dai and Cai maintain, "[i]n order to be well-received in the host market, state actor, managers, and employees, should be acculturated and glocalized to the host culture and give full play to its advantage of bicultural background." ${ }^{53}$ Such strategies and competencies will be useful when, thanks to the BRI, the future world becomes more inter-connected than ever.

\section{Promoting intercultural}

understanding is key

to strengthening

people-to-people

bonds under the BRI.

The BRI extends through Asia, Europe and Africa, where four great civilizations are located, involving 65 countries with different customs, religious beliefs, values and cultural traditions. As scholars have discovered, "intercultural understanding is important, because the basic values of the local people are hard to change; differences in living habits can be alleviated through cultural exchanges, though it takes time; differences incurred by management styles and management skills can be overcome by learning from each other, which is quite easy." ${ }^{54}$ Such efforts will not only help

\footnotetext{
${ }^{51} \mathrm{Wu}$ Minna and Ruan Chongyou, "Study on the Cross-Cultural Management of Chinese Enterprises under 'the Belt and Road Initiative,"' Advances in Economics, Business and Management Research, Vol. 58 (2018), pp. 353-355.

${ }^{52}$ Kang Lili et al., "Harmony in Diversity: Can the One Belt One Road Initiative Promote China's Outward Foreign Direct Investment?," Sustainability, Vol. 10, No. 9 (September 2018), pp. 1-28.

${ }^{53}$ Dai and Cai, "The Cross-Cultural Management of Chinese Enterprises in Poland under the Belt and Road Initiative - Based on PEST Model."

${ }^{54}$ Kang Lili et al., "Harmony in Diversity: Can the One Belt One Road Initiative Promote China's Outward Foreign Direct Investment?"
} 
prevent cultural conflicts between Indonesia and China in their exchange and cooperation, but they also foster a friendly environment for the BRI to proceed smoothly.

Apart from the state and business actors as the major players in international cross-cultural management, there are also individuals who are easily neglected but play important roles in international affairs, ${ }^{55}$ such as exchange students, visiting scholars, migrant workers, and tourists. For instance, exchange students are categorized as "individual actors" of international relations, because they migrate to other countries, interact with local people and people from different countries. ${ }^{56}$ They also promote host and destination cultures in the place where they stay or visit. The interview with Chinese students studying in Indonesia shows that Chinese students learn not only the language, but also about Indonesia in general, including the country's culture, tradition and people. They get some impressions, both positive and negative, based on their unique experience of living and studying in Indonesia. Most of them think that Indonesian people are kind, open-minded, easy to be friends with, and ready to help others. In the meantime, respondents also note the negative side like perpetual traffic jams and poor infrastructure; besides, they point out that Indonesians are more relaxed and sometimes show no respect for time. ${ }^{57}$ Since these students will be professionals in their own fields and likely become more deeply engaged in cooperation between Indonesia and China, exchange with their Indonesian counterparts should be further enhanced - like the exchange of scholars, tourists and workers - to add to mutual understanding and friendship between the two nations.

In short, development in international business, tourism, labor migration, and education prompts "holistic intercultural understanding"

${ }^{55}$ Daniel S. Papp, Contemporary International Relations: Framework for Understanding, 2nd Edition (London: Macmillan Publishing Company, 1988), pp. 93-95.

${ }^{56}$ Mitha Paramitaningrum, “Enhancing People-to-People Cooperation between ASEAN and East Asia Countries through Counterparts: The Case of Indonesian Students in Taiwan," Journal of ASEAN Studies, Vol. 1, No. 2 (2013), pp. 164-175.

${ }^{57}$ Tonny Dian Effendi and Zhang Lidong, "The Image of Nation: Case Study on Chinese Student Perception about Indonesia." 
among people. ${ }^{58}$ Understanding other countries' perspectives and their cultures help people to better appreciate other social-cultural conditions; ${ }^{59}$ and every practical business has a distinct "culture" to be understood and respected. Hence, promoting intercultural understanding is the strategy to strengthen people-to-people bonds under the BRI, so as to achieve lasting win-win results for both sides.

\section{Conclusion}

Despite the apparent benefits that the China-led BRI can bring to the country, Indonesia has yet to manifest an enthusiastic attitude toward the initiative. In addition to the enduring ambiguity of the concept of the BRI and negative coverage on the initiative by Western media, Indonesia is mainly concerned about the quality of Chinese investment and, more importantly, China's strategic intention behind the seemingly beneficial blueprint. Due to lack of mutual understanding about each other's culture, history and social realities, a mood of skepticism has prevailed among the Indonesian public on China and the BRI; even elites in various fields have developed a negative image of the initiative based on their personal interaction with their Chinese counterparts.

In order to strengthen cooperation under the BRI, China needs to promote intercultural learning with Indonesia (and other BRI countries), so that the BRI can truly represent a roadmap of how China and other countries become integrated into the world economy and reap benefits from this initiative. ${ }^{60}$ People-to-people bonds and cross-cultural relations must be

\footnotetext{
${ }^{58}$ The holistic approach means that when studying an aspect of intercultural gap, one does not treat that aspect as a distinct matter, but instead put it in the context of the whole intercultural system. This is very important, as different aspects or dimensions of societies are not closed systems, but are integrated with others. For example, corporate culture, religious practices, language communication, and politic structure are embedded in one another.

${ }^{59} \mathrm{Li}$ Wei, "Construction of Humanistic Silk Road with Sharing Cultures and Intercommunicating Souls Based on Chinese Civilization Wisdom," IOSR Journal of Research $\mathcal{E}$ Method in Education, Vol. 7, No. 2 (March-April 2017), pp. 1-5.

${ }^{60}$ Wang Yong, “Offensive for Defensive: The Belt and Road Initiative and China's New Grand Strategy," The Pacific Review, Vol. 29, No. 3 (2016), pp. 455-463.
} 
fused with mutual understanding between the two countries. ${ }^{61}$ Having a long history of friendly exchange and cooperation, there is immense potential to improve the networking of people and cultures between Indonesia and China for their "mutual connection of hearts" through the BRI, so as to build a community of shared future along the route.

${ }^{61}$ Liu Weidong and Michael Dunford, “Inclusive Globalization: Unpacking China's Belt and Road Initiative," Area Development and Policy, Vol. 1, No. 3 (2016), pp. 323-340. 